\title{
TWO-STEP CHEMICAL DECONTAMINATION TECHNOLOGY
} (U)

by W. N. Rankin

Westinghouse Savannah River Company

WSRC-RP--92-998

Savannah River Site

Aiken, South Carolina 29808

Other Authors:

This paper was prepared in connection with work done under Contract No. DE-AC09-89SR18035 with the U. S. Department of Energy. By acceptance of this paper, the publisher and/or recipient acknowledges the U. S. Government's right to retain a nonexclusive, royalty-free license in and to any copyright covering this paper, along with the right to reproduce and to authorize others to reproduce all or part of the copyrighted paper.

\section{MASTER}




\section{DISCLAIMER}

This report was prepared as an account of work sponsored by an agency of the United States Government. Neither the United States Government nor any agency thereof, nor any of their employees, makes any warranty, express or implied, or assumes any legal liability or responsibility for the accuracy, completeness, or usefulness of any information, apparatus, product, or process disclosed, or represents that its use would not infringe privately owned rights. Reference herein to any specific commercial product, process, or service by trade name, trademark, manufacturer, or otherwise does not necessarily constitute or imply its endorsement, recommendation, or favoring by the United States Government or any agency thereof. The views and opinions of authors expressed herein do not necessarily state or reflect those of the United States Government or any agency thereof.

This report has been reproduced directly from the best available copy.

Available to DOE and DOE contractors from the Office of Scientific and Technical Information, P. O. Box 62, Oak Ridge, TN 37831; prices available from (615) 576-8401.

Available in the public from the National Technical Information Service, $U$. $S$. Department of Commerce, 5285 Port Royal Rd., Springfield, VA 22161. 
WESTINGHOUSE SAVANNAH RIVER COMPANY SAVANNAH RIVER IABORATORY DIVISION

\author{
WSRC-RP $-92-9.98$ \\ KEY WORDS: Decontamination \\ Technology \\ August 14, 1992 \\ CC: W.L. Tamosaitis, 773-A \\ WSRC Records (4)
}

$\begin{array}{ll}\text { TO: } & \text { W. E. Stevegs 773-43A } \\ \text { FROM: } & \text { W. N. Rankin, 773-A }\end{array}$

TWO-STEP CHEMICAL DECONTAMINATION TECHNOIOGY (U)

SUMMARY

An improved two-step chemical decontamination technique was recently developed at INEL. This memorandum documents the addition of this technology to the SRTC arsenal of decontamination technology. A two-step process using $\mathrm{NaOH}, \mathrm{KMnO}_{4}$ followed by $\mathrm{HNO}_{3}$ was used for cleaning doorstops (small casks) in the SRTC High Level Caves in 1967. Subsequently, ore aggressive chemical techniques have been found to be much more effective for our applications. No further work on two-step technology is planned.

\title{
DISCUSSION
}

- Decontamination operations often consist of removing films containing radioactive material from Type $304 \mathrm{~L}$ stainless steel surfaces. In applications where damage of the stainless steel surface is a concern, such as the inside of pipes in reactor cooling systems, strong acid cannot be used. In these applications multiple-step procedures are often used. One of the first successful procedures for use in this application was developed at the U.S. Steel Laboratories in 1951. The procedure consisted of treatment with alkaline permanganate $\left(\mathrm{NaOH}, \mathrm{KMnO}_{4}\right)$ followed by soaking in $\mathrm{HNO}_{3}$. The alkaline permanganate changed the character of the film on the stainless steel to a more porous and reactive form, which was then dissolved on subsequent contact with the $\mathrm{HNO}_{3}$.

There have been many improvements of the multiple-step procedures. Turco markets chemicals for a two-step process. First, Turco 4502 is applied to the surface being cleaned. This pre-decontamination oxidizer and conditioner is a blend of potassium permanganate and 
a wetting agent. Next, Turco 4521, which contains oxalic acid, is applied to the surface. These chemicals condition and remove the film from the surface of the stainless steel. Recently, J.G.Scott at the INEL found a combination of oxalic and nitric acids is very effective in use with surfaces pretreated with Turco 4502 . Results of two plant trials show that the oxalic nitric combination $\left(0.5 \mathrm{M} \mathrm{HNO}_{3}, 0.5 \mathrm{M}\right.$ oxalic) is about four times more effective in removing contamination than either Turco 4521 or plain oxalic acid.

In applications where damage of the surface is not a concern a combination of strong acids is effective. ASTM A 380-88, "Standard Practice for Cleaning and Descaling Stainless steel Parts, Equipment, and Systems", recommends a combination of nitric and $\mathrm{HF}$ acids for this application. In decontaminating the cavities of the 5320 plutonium oxide shipping containers for fire testing an etch using $3.5 \mathrm{M} \mathrm{HNO}_{3}$ and $0.04 \mathrm{M} \mathrm{HF}$ at 50 degrees $\mathrm{C}$ was very effective. In decontaminating the SRTC High Level Waste Trajler not only surface films but also a layer of metal had to be removed. An etch using $3.5 \mathrm{M} \mathrm{HNO}_{3}$ and $0.04 \mathrm{M} \mathrm{HF}$ is recommended to perform these operations at room temperature.

RROGRAM

No further work on two-step decontamination technology is planned. 

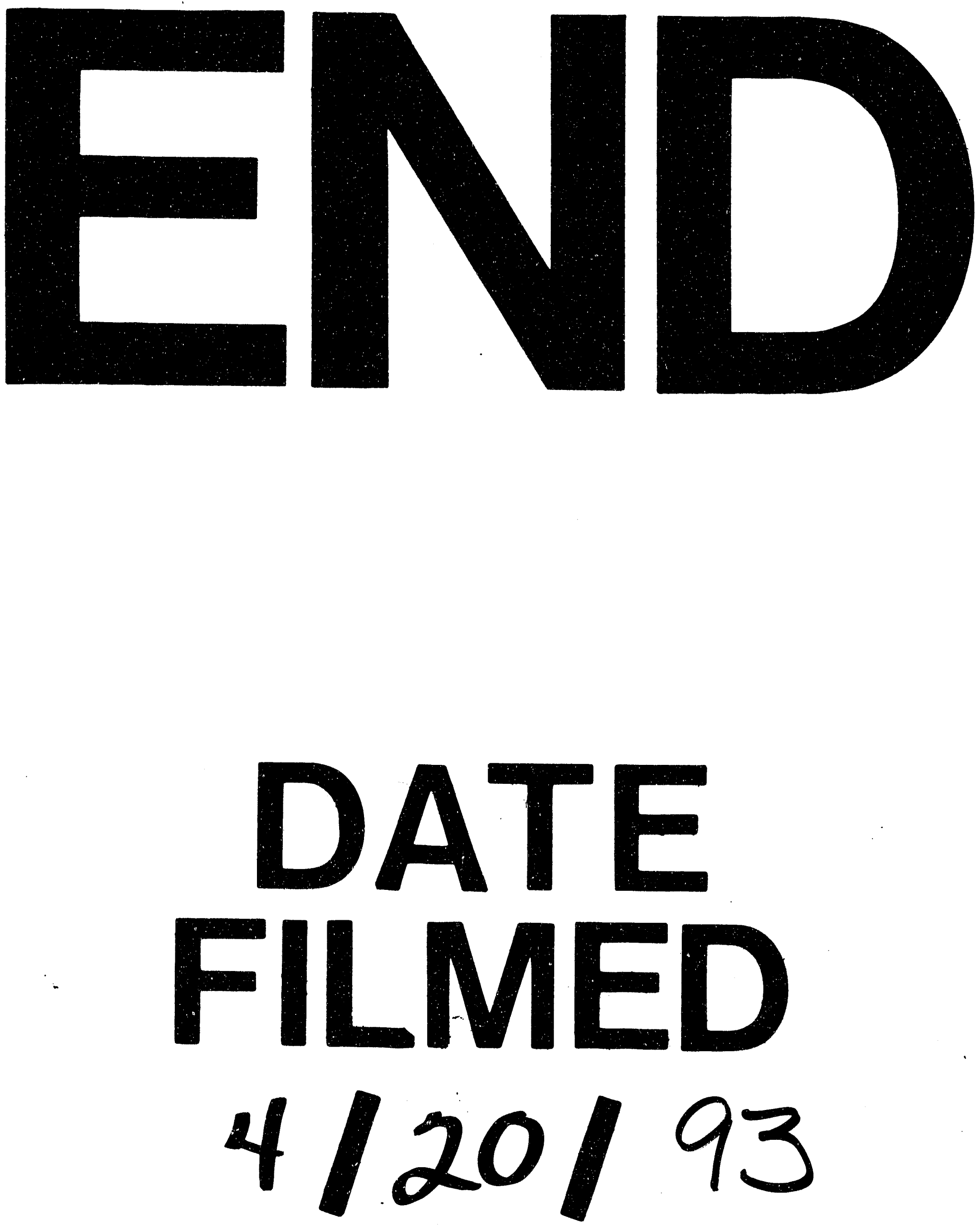


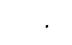

